\title{
Philosophical Literacy: \\ Dialogue on a Pedagogical Experiment
}

\section{LENA MCCOURTIE \& PETER MILLER}

University of Winnipeg

\begin{abstract}
This paper seeks to contribute to the ongoing debate in universities about literacy, the link between writing and academic success, and writing in specific disciplines. It reports the major phases in the design and implementation of a team-taught curriculum which integrated two half courses in writing and philosophy. The major objective was to develop philosophical literacy among students as a groundwork for future humanities courses. The unifying motif was "dialogue" which facilitated the negotiation between two members of faculty with different areas of expertise, the concept of philosophy as dialogue, and the student-teacher relationship as dialogue. Comments are made about some of the difficulties and uncertainties which students experienced initially, as well as certain modifications which were made to the curriculum. The successful completion of a wide range of differentiated tasks and the major assignment, a complex argumentative research paper, indicated the extent to which students had achieved the goal of philosophical literacy. The experiment

We wish to thank students of the integrated course who made this paper possible, and others to whom we made reference; Alexandra Lumpp, Zoltan Homola, Marco Almeida and Axel deAvila. We greatly appreciate the constructive criticism of the paper which was given by Dr. Jon Young, Dr. Anthony Paré and Dr. Brian Turner, as well as the anonymous reviewers. A special word of thanks goes also to Dr. Hatem Howlader and Dr. Liliane Rodriguez.
\end{abstract}


raised a number of challenging theoretical and pedagogical questions, some of which are answered in the final section of the paper, while others still need to be researched.

\section{Résumé}

Cet article vise à prendre part à la discussion ec cours dans les universités sur le fait de savoir lire et écrire, le lien entre la rédaction et la réussite scolaire,ceci dans des disciplines particulières. Il rend compte des phases principales de la conception et de la mise en place d'un curriculum enseigné en équipe, auquel deux demi-cours en rédaction et en philosophie ont été intégrés. L'objectif principal était de développer chez les étudiants leur capacité philosophique en lecture et en rédaction en vue de leurs cours futurs en sciences humaines. Le facteur intégrateur était le "dialogue" qui a facilité les négociations entre deux membres de la faculté de deux domaines de compétence différentes - ainsi que le concept de philosophie comme dialogue, et les relations entre l'étudiant et le professeur comme dialogue. Des remarques sont faites sur certaines difficultés et incertitudes rencontrées par les étudiants au début du cours, ainsi que sur des modifications apportées au curriculum. La réussite de diverses tâches différenciées et du devoir principal, une dissertation de recherche complexe et dialectique, indiquent dans quelle mesure les étudiants ont atteint la capacité philosophique de lire et d'écrire. L'expérience a soulevé un certain nombre de questions théoriques et pédagogiques assez difficiles, dont certaines trouvent une réponse dans la partie finale de l'article, alors que d'autres nécessitent des recherches plus approfondies.

\section{Introduction}

Many colleges and universities have long recognized that students need to develop a range of social, cognitive and linguistic abilities in order to achieve success in a literate, knowledge-based society. Moreover, scholarship and full cultural participation require fluency in interpreting and creating written texts. Indeed, so central is the role of writing in all aspects of the curriculum, that many educational institutions have implemented a wide range of writing initiatives. In 1987, for example, the University of Winnipeg created a Writing Program with core writing courses supplemented by "writing intensive" courses in the academic disciplines. Over the years, the Program has stimulated discussion of and 
experimentation with writing pedagogy. In one such experiment, the authors of this paper, one from the Philosophy Department and the other from the English Department/Writing Program, created an intensive team-taught course which integrated two previously separate half courses in writing and philosophy. The major objective of our efforts was to develop philosophical literacy among our students as a groundwork for future humanities courses.

Such an objective at once raises theoretical and practical questions, for example, what are the logistics of designing a curriculum that is both conceptually unified and pedagogically sound? The rich corpus of literature and research which exists on various writing initiatives provided a useful starting point. College Composition and Communication, Vol. xxxvi, May 1985 deals with writing in the social sciences, science and philosophy; Russell (1991) provides an historical overview of writing in the disciplines which extends over 120 years; while Odell (1993) analyses some of the theoretical and practical issues of writing in the disciplines.

But, although these provided clues to our tentative questions, there were no definitive curriculum models which we could adopt. Kauffer and Young, in analyzing the theoretical complexities of their own collaborative interdisciplinary writing project in biology and rhetoric, rightly observed "that a strong program . . . must be shaped to the peculiarities of its environment ... since all academic environments differ, often substantially" (1993, p. 7). So, what special characteristics of the University were relevant to the integrated Writing and Philosophy course? The two critical factors which helped to shape the experiment are the social context of the University, and the uniqueness of the particular cadre of students.

The environment of the University of Winnipeg is that of a small undergraduate liberal arts institution, located in the inner city, with a total enrolment of about 7,000 students, half of whom receive their education on a part-time basis. But the ethos, ambience and culture of the institution need to be understood in relation to a philosophy informed by (a) an access mandate, (b) a strong commitment to the central role of writing in and across the curriculum, and (c) the seemingly divergent goals of access and excellence.

The challenge of providing greater accessibility to students who were traditionally excluded from higher education has been addressed by the University of Winnipeg as well as other Canadian universities (see Canadian Year Book, 1992; Forbes, 1993; Smith, 1991). For example, a 
President's Task Force of the University of Winnipeg conducted research and held consultations locally, nationally and internationally, from 1988 to 1990 , in order to provide answers to the complex and controversial issues of "access" and educational equity.

The findings, documented in Diversity and Excellence in Education: An Integrated Approach to Improving Accessibility at the University of Winnipeg (1990), target several groups of non-traditional students, who, for various academic, cultural and economic reasons, had been underrepresented in institutions of higher learning. These include

aboriginal peoples, immigrant and ethnic groups . . . from South-East Asia, the Philippines, the Caribbean Islands, Central and South America and the Indian sub-continent . . . traditional working-class communities with low postsecondary rates .... and the disabled. (p. 6)

Admission standards are linked to the broader issue of access. The University of Winnipeg's General Calendar, (1993-1994, pp. A2-3) documents three different points of entry for Regular, Conditional, and Mature students:

1. Undergraduates who qualify for Regular Status are those who have completed a Manitoba High School Diploma, with a minimum average of $60 \%$ on the three best university subjects, of which at least one is either English or Mathematics.

2. Those whose average lies between $50 \%$ and $60 \%$ are admitted on Conditional Status.

3. Others, who have not obtained the requisite academic qualifications, or have not graduated from high school are admitted on Mature Student Status, if they are at least 21 years of age in the calendar year in which they register.

(See Procter (1995) for details of higher admission standards for Ontario universities).

Given the access mandate and a heterogeneous population, then the importance of the Writing Program becomes central to the curriculum of the University as a whole. At one level, internal reports like the Senate founding document, 1986; Diversity and Excellence in Education: An Integrated Approach to Improving Accessibility at the University of Winnipeg, 1990; and Report of the Writing in the Disciplines Subcommittee of the Academic Standards Committee, 1993 articulate a 
vision and provide mission statements about writing in the institution. At another level, McManus (1991), Smith (1991), Schryer and Steven (1994), and Graves (1994) place the University of Winnipeg's program in a national perspective.

But, the discussion of admission standards needs to be balanced by the fact that the institution does attract a large cohort of high calibre undergraduates to whom further reference will be made. It is not surprising, therefore, that the University maintains a strong commitment to the twin goals of access and excellence. A Program Review Document: The Relation of Our Past to Our Present and Future (1990) sharply reinforces the two seemingly divergent but achievable goals:

1. to make meaningful access to the University possible for all entering students, including those at high risk of failure, in keeping with the access mandate of the University; and

2. to contribute to the overall intellectual calibre of the University, in keeping with the University's commitment to excellence. (p. 4)

This, then, was the background against which our experiment was conceived. Our task was to devise a curriculum aimed at developing philosophical literacy for a very diverse cohort of entry-level students. Some of these would have fallen in category (1) above, because undergraduates with marks of $80 \%$ or more in Manitoba High School English, with a grade of at least 5 in Advanced Placement, and 4 in International Baccalaureate are exempt from the writing requirement which is the focus of this paper. It must be noted at the outset that 39 students first registered for the course, but it was highly unlikely that these numbers would have remained constant over the period of two terms. The section on Instructors' Evaluation records in some detail the combination of factors which gradually reduced the class to 26 undergraduates over the period of two terms.

The course was indeed very time consuming, but it is difficult for us to give any accurate assessment of the total number of hours expended, because we did not keep a log. The actual contact time was $21 / 2$ hours per week: two classes of equal duration. Then, there was an optional period of 45 minutes at the end of a class where students were free to consult either or both instructors. The most labour-intensive aspects of the experiment, however, were the initial negotiation of different epistemological space, the actual planning and implementation of the new curriculum, writing as 
a recursive process which requires that instructors read more than one draft of a paper, and the dialogue which facilitated the work on an ongoing basis. These are discussed in the following section.

Because we were virtual strangers who had no prior knowledge of each other's pedagogy or philosophy, the way forward was an exploratory use of dialogue to mediate the educational materials which we exchanged. This approach was inevitable. Indeed, the concept of dialogue, or "dialogic encounter," as used by Freire (1970) and Baktin (1981) was critical to our deliberations, as it operated implicitly and explicitly on a number of levels in course design and implementation. In our case, dialogue

- characterized the relationship between two faculty members from different discourse communities who met as equal partners, each bringing a different kind of expertise to the discussion.

- describes the negotiation, the compromise, the dialectic, the problematizing, and the search for answers in trying to integrate philosophical content and writing pedagogy.

- underscores the teacher-student relationship at different levels.

- occurred among students working in pairs, small groups or the whole class as they shared their understanding of different facets of course content and began "the social construction of knowledge," however tentatively at first.

- was critical at different stages of the writing process, in exchanges between peers and between students and instructors.

- expresses the essence, the very nature of philosophy and highlights the reciprocities in language that are so important to philosophical and rhetorical practice.

We have divided our paper into four parts. To capture our concerns, questions, thinking and planning, we adopt a dialogue format for Part I, which deals with the history and rationale for the course. In the dialogue, "WP" and "PD" designate, respectively, the Writing Program and the Philosophy Department. The rationale developed in Part I leads, in Part II, to a summary of the resulting curriculum design with assignments which operationalize our pedagogical principles, and illustrations from students' work. Then, in Part III, we initiate an informal evaluation of 
the first year of our experiment, and, in Part IV, we return to the format of the dialogue as we address a number of questions and concerns.

\section{Part I - Developing a Course Rationale}

WP: Let me briefly set the stage. Early in the summer of 1993, PD approached the Writing Program with a proposal to link an introductory philosophy half course, "Thinking About Moral Issues," with the required core writing course. To get us started, suppose you tell us, PD, how you and your department have handled literacy issues and then explain why you approached us to suggest a philosophy/writing link?

\section{Defining the problem: Literacy and the teaching of philosophy}

$P D$ : Philosophy, as we practice it, requires that students demonstrate both willingness and sufficient writing ability to engage original theoretical works written over the last 2,500 years. Our department has had a long-standing concern with students' literacy, but in different ways at the senior and introductory levels. When students in senior courses flounder at basic writing skills, both we and they are frustrated and the subject matter is compromised. On the other hand, in our introductory courses, most of us recognize an obligation to try to develop some of the skills required in our senior courses. We do this by several means, including a variety of shorter assignments with a simpler task than a full-blown essay and the options of submitting paper proposals and drafts for early feedback before the final submission of an essay.

However, there are several constraints which limit the developmental literacy work that we do in our philosophy courses even at the introductory level:

- Class sizes of 65 limit the individual help we can give. We cannot chase down the lost sheep.

- The significant amount of material we feel obliged to "cover" in survey courses leaves very little class time to discuss or practice recursive composing processes, such as invention, drafting, revision and editing.

- Most of us lack a background in how to develop writing skills and strategies. 
- We are often particularly frustrated in instructing students for whom English is a second language who have not fully acquired the resources of English. I am sure the frustration is mutual, as they struggle to write in English about texts they find largely incomprehensible.

- Except for class reports in honours seminars, there is often little experience in presenting writing to peers and soliciting their feedback.

Thus, we in philosophy regularly confront problems of literacy, and most of us have, off and on, revised our pedagogy to address these problems. This was the case, when, in that fateful "summer of '93," I went to the Writing Program coordinators with a proposal to link introductory philosophy with a writing course. WP, when I approached the Writing Program, you were the one to respond. Can you tell us why? Perhaps you can begin with a summary of the concerns which guide you as you teach a section of the required writing course.

\section{Defining the problem: Literacy and the teaching of writing}

WP: A free-standing writing course poses a number of challenges. Students do not always bring the most positive attitude to a class which is mandatory. In addition, some admit that the multi-faceted task of writing intimidates them, while others refer to negative experiences prior to entering the University. So, a combination of factors contributes to the concerns which I have formulated in the following questions:

1. How can I devise a curriculum which involves and engages students - one which motivates and interests them, and is tailored to meet their needs?

2. What should be the content of the course?

3. To what extent are the assignments disembodied, when there is no recognizable body of content in which the various activities and processes are embedded?

4. What are the most effective strategies to help students to think creatively and critically and master the skills of argumentation?

5. How can I help students "enter the conversation," and become initiated into the "language of academic discourse"? 
6. Are there skills, understandings, and insights which can help students to meet the diverse expectations of other disciplines?

$P D$ : I have asked those questions too, so despite our different backgrounds, we shared a common set of concerns in developing our integrated course. Don't you wish the answers were as straightforward as the questions? I confess that I am particularly interested in the "big ideas" by which people interpret their experience and guide their actions, that is, their philosophy. So, can you tell me, WP, as you try to answer the pedagogical questions you posed, what are some of the "big ideas" that have guided you? How would you sum up your philosophy of writing instruction?

\section{A philosophy of writing instruction}

WP: My philosophy is by no means fixed and inflexible. It is constantly being shaped and reshaped by a number of variables. At one level, it operates, in the words of Lindemann $(1987$, p. 3), as a kind of "conceptual framework" against which I deal with the explosion of knowledge, the diverse theories and approaches in the field, as well as examine and reexamine my pedagogical assumptions about the processes of writing. Then I try to bridge the gap between theory and practice. At another level, my teaching pedagogy is sensitive to the University's vision for the Writing Program, to the writing process as I envision it, to the role of "formative" evaluation in the development of students' writing abilities, and to the diversity within the student body.

If linguistic, cognitive and writing abilities were conceptualized as a complex, multidimensional continuum, then students could be said to fall at different points on the spectrum. At the lower end, for example, there are students for whom English is a second, third or even a fourth language. Some of these learners have thoughts which they could have expressed fluently in Panjabi, Arabic, Amharic, Tagalog, Spanish or Cantonese. However, lack of adequate resources in English might contribute to oral or written discourse in which the "meanings" which the speaker/writer intended are largely obscured. Here Vygotsky's (1986) Thought and language and the exploration of the complex interrelationship between language and thought and the "inner speech," the "mental draft" which precede writing become particularly relevant. However, my philosophy of writing instruction must be tailored to deal with students at different points on the spectrum of writing abilities. 
Sociolinguistics and research in rhetoric and composition all confirm that writing does not occur in a vacuum, but in a complex social/rhetorical context. Writing is a series of processes: social, cognitive, linguistic and rhetorical; the picture of the lonely author who writes "cold" is no longer strictly accurate. It is therefore necessary to provide a range of situations in which students can gain some insight into the way these processes interact to produce a text. Students get tremendous cognitive support as they brainstorm a topic together, engage in a range of pre-writing activities, share ideas in a class or in small groups, take opposing viewpoints and enter into real dialogue with one another and the instructor.

Students also need to be helped to understand how rhetorical variables such as audience, purpose and "voice" or perspective contribute to shaping writing in different genres. Although the concept of audience is not particularly easy for students to internalize, yet it remains what Odell (1993, p. 294) refers to as the most important "mental construct." A major objective is that students gradually learn to identify and analyze the nature of their audience and decide which organization of ideas, linguistic choices, level of diction, and forms of evidence and argument seem most effective. Because composition is taught in the Writing Program as a staged recursive process, students get opportunities to test and apply the "mental construct" of audience as they critique, review, and provide oral and written comments on the original drafts of those in their groups, as well as proof-read and edit the later drafts.

I also believe that "formative" evaluative comments are very important to facilitate the ongoing language and writing development of students. Although this approach is very time consuming, it seems particularly crucial for "basic" writers and introductory students, all of whom experience a measure of anxiety about grades. Some are returning to school after a long hiatus, while others are struggling to make the transition from high school to university. So they present a text with the understanding that I will assume the role of "intermediate audience" and will provide comments which enable them to refine or revise the text before submitting it for summative evaluation and a grade. This learning experience allows them to play an active rather than a passive role in assessing their work.

Students are also placed in a non-threatening one-to-one conference situation, which has certain spin-off effects. As these writers dialogue with me and seek clarification of cognitive, linguistic and rhetorical 
issues, they begin to acquire a whole new language to interpret the activity of writing. This metalanguage not only helps them to reflect on and analyze a particular text, but could assist them in the creation of other texts. More importantly, these writers gradually develop insights which inform the various peer review processes.

$P D$ : There is no doubt that the complex social, linguistic, cognitive and rhetorical processes of writing make greater demands on some students than on others. I, therefore, have a number of questions about those for whom English is a second language. Are writing skills affected by the cultural or linguistic background of students?

WP: Perhaps, the most critical factor in the writing process is the stage or level of students' acquisition of the language in which they are expected to write. Every new language has its own way of encoding and expressing meaning. If language learners have not yet acquired an adequate vocabulary, the syntax and morphology, and the semantics or meaning component of English, then writing will pose problems irrespective of their cultural and linguistic background. Globally, applied linguists focus on the systematic investigation of the discourse of language learners from widely disparate linguistic and cultural backgrounds in order to become more informed about the processes of language learning, as well as to improve pedagogical practice. What is interesting is that their findings show that students for whom English is a second language are likely to experience some of the same difficulties of vocabulary, syntax and morphology and semantics, irrespective of their linguistic and cultural background.

The following comments from two students in the course also throw some light on the question:

1. My background is French. I often find myself thinking in French, and then trying to translate into English. In some instances, I cannot find the words I really want in English.

2. I really love to write in Spanish, my first language, but English is a different matter. Since I came to Canada five years ago, I began to learn the language. Sometimes, I am afraid to write, because of my lack of confidence. I do not know enough words, I do not know how some words are written, and my grammar is poor.

$P D$ : Are writing skills easier to develop in some languages and cultures than in others? 
WP: There are so many complex variables which contribute to the acquisition of literacy in a second language, but there may be two slight leads here. Corder (1981, p. 95) advances the theory of "language distance," or the measure of the 'linguistic' or structural distance of any particular language from English.". This concept is linked with language families, and the genetic relatedness of one language to another (see Gleason, 1961). For example, German, English and Dutch belong to the Germanic family of languages. The assumption is that someone who is literate in German could acquire English more readily than Arabic, Chinese or Japanese.

Although Corder (1981) concedes that there are theoretical and practical difficulties in measuring degrees of language distance, he suggests that the principle is widely reported. The following examples might provide slight anecdotal evidence. Zoltan, a Hungarian, moved to Germany with his parents and then became fully literate in German. When the family moved to Canada, Zoltan stated that he found the acquisition of English very, very easy. This trilingual student is a very competent writer in English. Another example comes from two speakers of the Romance family of languages. Marco speaks Portuguese to Axel, who in turn addresses him in Spanish. Each claims that he understands at least $70 \%$ of what the other is saying. If Marco gave serious attention to the systematic study of Spanish and Axel did the same for Portuguese, both might achieve literacy in another Romance language without too much difficulty.

$P D$ : Is there any research on the development of writing skills in different languages and cultures?

WP: In the field of Second Language Writing, I have not met any systematic long term investigation comparable to the study conducted by Britton, Burgess, Martin, McLeod and Rosen (1975) on the written language of British 11 to 18 year olds: The Development of Writing Abilities (11-18). Much of the literature and research deal in general with English as a Second Language generated in ESL writing classes, which are usually a mixture of students from a wide range of linguistic and cultural backgrounds. (See, for example, Farr \& Daniels, 1986; Kroll, 1990; McKay, 1984; Shaughnessy, 1977).

There is one study, however, conducted by Moser and Raphan (1993) which focused on the writing development of Russian students in an ESL program in the City University of New York. Students who have not performed well on an essay test administered to all incoming undergraduates, 
and those whose native language is not English, are placed in one of the following levels of writing classes: low, low-intermediate, high-intermediate and high. The number of Russian students whose performance placed them at the top end of the spectrum was so great that it generated further study.

Moser and Raphan found that there were a number of contributory factors. The Russian students had brought with them familiarity with literary texts and impressive analytic skills, as well as some foundation in English Grammar. Another critical factor was "integrative motivation," which reflected itself in their "social networking," and immersion in English through classes offered by New York agencies, as well as jobs and apartments where they would have to use English. Moser and Raphan (1993) conclude by saying that

this group of language learners . . . came to us with formal academic experience, with a strong desire to succeed in America. They are focused on becoming part of the American mainstream and are aware of how important the acquisition of English is to the realization of their goals. (p. 51)

$P D$ : As you answered these questions, I kept thinking about the strong link between writing and academic success in higher education and the ways in which this modality can empower or disempower, confer or deny access to students. But there is another train of thought which I would like to explore briefly. In one of our conversations, I was particularly struck by your reference to Vygotsky's (1986) "inner speech which precedes writing." Did you know that Plato, that ancient master of written dialogue, described thought, in essence, as an inner dialogue in which we try out different positions, raise and answer questions, and form a settled judgement when the different voices within us reach agreement about some point? (Plato 1961b, 263e-264c; Plato 1961c, 189e-190a).

As a cautionary note, we might also remember that Plato, although one of history's most skilful writers, was also very suspicious of the written word, which can in beguiling ways freeze distortions of the truth in authoritative language to stifle further thought (1961a, 274e-276a). Most of his writing takes the form of dialogues between his mentor Socrates and other Athenians. This format reminds us that each utterance appears in the context of other utterances and a critical line of questioning may lead one to abandon or modify or interpret differently what was earlier affirmed. 
Plato's admonition, and his practice, was to see a written text not as expressing a fixed and final set of ideas but as itself a phase in a larger dialogue, the living, and shared, enterprise of creative and critical thinking. Indeed, to keep the project of investigation and discussion and learning alive, Plato invented the first western university, the Academy of Athens. That is how I understand your earlier reference to "the great conversation" of intellectual practice, which we want to encourage our students to enter and continue.

Essential to this model is the notion that philosophical discourse is a two-way street, a give and take in which we speak or write our own thoughts, but do so responsively to what others have to say and to the topic, circumstances, purposes and audience of our communication. Good dialogue requires that the participants develop their listening and reading skills as well as their speaking and composing skills.

But how might students best enter the arena of academic discourse? Please go on now to tell us something of the debates that have emerged in your discipline about this topic. I know that the Writing Program, after being in operation for five years, underwent a review. What did the reviewers have to say about these matters?

\section{Writing program review and emerging debates}

WP: Reviewers directed attention to the differing theoretical insights and pedagogical practices employed in the two components of the Writing Program - the core writing and the writing in the disciplines courses. Core courses, by and large, introduced students to a cognitive model of writing which oriented them to "a variety of heuristics or intellectual strategies designed to help them generate and organize ideas, set writing goals, consider readers, plan, draft and revise" (Paré \& Segal 1993, p. 9). But one caveat which they mentioned strongly was that these practices do not necessarily transfer into other fields within the academic community. In contrast, Writing in the Disciplines more closely reflects social epistemic theories of writing which "recognize the diversity of writing products and processes across the disciplines and that ... the intellectual activity of writing changes from field to field" (Paré \& Segal, 1993, p. 10).

If, then, there were problems with the transference of the cognitive skills learned in a free-standing writing course to particular academic disciplines, the pedagogical challenge became how to incorporate the cognitive model of rhetoric into the social epistemic model and so meet 
the diverse writing and cognitive expectations of different disciplines. Since a major objective of the Writing Program is that students become mature and competent writers in different curriculum areas, the reviewers' recommended solution was to link writing with disciplinary courses. Because the intellectual climate in the University was particularly favourable to different forms of interdisciplinarity, this recommendation found strong support from The Report of the Internal Committee to Review the Writing Program (1993).

These reviews effected a meaningful convergence and crystallization of ideas for me. Integrating philosophical content with writing would go a long way to addressing our mutual concerns as well as moving students towards the goal of philosophical literacy, in accordance with Paré and Segal's (1993) model:

Literacy is a developmental process, a continuum of linguistic, cognitive, rhetorical, and social abilities that begins with simple encoding and decoding of written language and continues on to [more] sophisticated command of discipline-specific discourse. (p. 10)

First, students constitute a community of novitiates who will begin to read, think about and discuss real academic discourse, which with the help of your expertise and a dialogic teacher-student relationship results in the "social construction of knowledge," rather than its mere transmission. As they begin to reflect on and critique academic texts, they also become more and more oriented to the writer's use of rhetorical variables: the way his/her sense of audience, purpose, voice and use of language shape the discourse.

Then as students work through the multi-faceted processes of writing, this modality can be used to clarify their thinking, as they learn to write and write to learn. More importantly, their understanding of the rhetorical variables in texts can be applied to their own writing. So there is a strong possibility that students could move towards the production of more "discipline-specific discourse." But questions still remain. What constitutes common ground? What insights and understandings will facilitate students in other disciplines?

$P D:$ I raise these questions in a slightly different way. Is there a single form that literacy can take to satisfy at once the diverse expectations of (1) personal significance, (2) utility in employment, and (3) scholarly excellence in a variety of disciplines ranging from physics to history or 
poetry? Evidently not, to judge from the immense disparities between genres and very different levels of achievement a given individual would be expected to realize in them. Indeed, some argue that rhetorical differences between diverse disciplines may express and create such contrary mindsets that success in one promotes failure in others. For example, recent criticisms of postmodernist trends in the humanities propose that they disempower students for the pursuit of truth in mathematics and the social and natural sciences as well as in more traditional approaches to the humanities (Gross \& Levitt, 1994). Still, might there not be some precepts and skills common to these diverse rhetorical forms?

WP: While I understand your reservations, I am prepared to posit the view that there may be three interrelated denominators common to a variety of disciplines: students' control of language, the development of their rhetorical abilities, and the skills of argumentation. The first centres around a student's control of language in a wide range of situations and an understanding of the flexibility of its use in different rhetorical modes. As Berlin (1987) points out, "language is a speculative instrument that enables us to understand and change the world, and the study of the way language does this is rhetoric" (p. 177).

The development of students' rhetorical skills is highly significant and may well constitute common ground. Indeed, Schmidt and Vande Kopple (1995) express this view: "we believe that those who are skilled in rhetoric are those who will be able to continue enlarging the numbers of discourse communities they can communicate within"(p. 6).

Although it is unwise to generalize from one example, recently Alexandra Lumpp, a third year German exchange student, reinforced Schmidt and Vande Kopple's view as she reflected on the power of the spoken word. First she referred to the three components of Aristotelian speech: the logos, the ethos and the pathos, which give speech a certain persuasiveness. Then she adds:

And even in our private lives, though we may never speak to a vast audience, rhetoric can help us to organize our thoughts, to explain them clearly to other people and to be persuasive. The one who masters rhetorical skills is in a position of power over other people. However, rhetorical skills are not enough to obtain a powerful position in a conversation.

The final sentence leads her into consideration of other sociolinguistic variables which contribute to the power relations in a conversation. 
The third common denominator might well be described as the skills of argumentation. Popper $(1959$, p. 15) refers to "the one method of philosophy" which is equally applicable to the other disciplines including the natural sciences. That is the method of rational discussion. To move this more closely to writing pedagogy, Elbow (1991) broadens the concept as he searches for that which he could teach in first year writing courses and argues that

what would seem central to such a conception of academic discourse is the group of reasons and evidence rather than just opinions, feelings, experiences: being clear about claims and assertions rather than just implying or insinuating; getting thinking to stand on its own two feet ... rather than leaning on the authority of who advances it or the fit with who hears it (p. 140).

Elbow points out that in reconceptualizing academic discourse in this general way, he was in fact "describing a major goal of literacy." These reflections seemed to synchronize with the ideas you advanced in your booklet, Philosophical Literacy, which you gave me at the beginning of our discussions.

In trying to understand what aspects of our course could serve as a groundwork for future humanities courses, I have referred to the ideas of Schmidt and Vande Kopple, Berlin, Popper and Elbow, but what about the views of professors in different disciplines in this University? In order to test my tentative assumptions about what constitutes common ground and get greater insight into disciplinary expectations in the University, I approached a number of my colleagues and asked specific questions. For example, when did they judge that a student had entered the discourse community and what constituted excellence in students' papers? From professors in Classics, English, Sociology, Political Science, History and Philosophy Departments, I extrapolated the same three interrelated common denominators: students' control of language, the development of their rhetorical abilities, and the skills of argumentation.

So far, Part I has highlighted our mutual concerns about the writing process, generated a course objective of philosophical literacy with possible application to other disciplines, articulated a philosophy of writing instruction to inform the integrated course, discussed the nature of the students for whom the course is being designed, and made central the concept of dialogue as a unifying theme. We turn next, in Part II, to a description of the curriculum we built upon this foundation. 


\section{Part II - Design of a Common Curriculum and Assignments}

A major task was the design of a curriculum which would meld together the essence of the philosophy course with those practices and processes which are unique to the Writing Program and achieve the following major objective: to help students internalize and practice philosophy as dialogue and to acquire philosophical literacy which would serve as groundwork for other courses. Exchange of material, countless hours of debate and mountains of used paper were the order of the day.

But there is one way in which this course differed from other interdisciplinary initiatives. Whereas the few other linkages between writing and academic disciplines at our university have retained separate, but parallel courses, our own experiment created a single unified writing/philosophy course having a single set of requirements, thanks to the concurrence in basic assumptions (set out in Table 1) that we were able to achieve. Moreover, when it came to the actual course delivery, we were both present in the classroom together all of the time, but traded off who would initiate the discussion.

Table 1

\section{Basic Course Assumptions}

Assumptions about ethics: the two levels

- Application: analyzing moral dilemmas

- Theory: reflecting on moral concepts and values

Assumptions about critical thinking

- Clarifying and critiquing issues, arguments and assumptions

- Seeking reasons and evidence for claims

- Asking and answering questions in constructive dialogue

Assumptions about writing

- Writing as a complex set of processes: social, cognitive, linguistic and rhetorical

- Writing as staged and developmental: towards a theory of difficulty

- Significance of the rhetorical variables, which enable students to identify and evaluate rhetorical strategies of writers and which also inform their written assignments at every level

Synthesizing assumption: Philosophy and Rhetoric as dialogue 


\section{Course content}

The philosophical content of the course combined ethics and critical thinking under the rubric "Thinking about Moral Issues." Course readings included four dialogues of Plato in The Trial and Death of Socrates (1977); an anthology, Ethical Issues: Perspectives for Canadians (Soifer, 1992); Writing: A College Handbook (Heffernan \& Lincoln, 1994); and a range of specialized handouts, such as "Notes on Ethics" and Philosophical Literacy (Miller, 1993). We also used films and videos.

The character of Socrates in Plato's writings provides a classic model of philosophy as an historic, but continuing dialogue emerging from a critical look at crucial issues of understanding and well-being. Moral issues lend themselves well to discussion and debate, and provide a vehicle for attending to techniques of critical thinking and rhetoric as well. The dialogical strategies and precepts described in Part I informed the reading, discussion, analysis and creation of texts.

\section{The teacher-student relationship as dialogue}

Since the successful implementation of the curriculum would depend to a great extent on the level of participation and interaction of the students, both teaching strategies and classroom climate were geared to facilitating the learning process. First, we tried to establish a friendly, socially interactive community, as we learned the names of the students quickly, and they, in turn, learned the names of their peers. This was a tacit assumption in the Freirean sense that they were "subjects" not "objects," that they had an identity and a name and that their thoughts, feelings and ideas were important.

Because the philosophy of teaching was non-authoritarian, because the approach was not the mere transmission of knowledge, the teaching strategies included mini-lectures, whole class discussions, group work, the use of detailed study guides, and reports from group leaders, while films and videos contributed to a multi-sensory approach to teaching. Thus, students were led to make discoveries as they shared their understandings in small groups or in the whole class.

Dialogue operated at another level, as great value was placed on students' input in the form of early formative evaluation for the course. Because we regarded them as subjects, and as active partners in the learning process, we asked periodically for their responses to the course, its strengths, if any, weaknesses and suggestions for improvement. The 
periodic formative evaluation of those for whom the course was designed in the first place would sensitize us to students' felt needs and areas of concern. These enabled us to make adjustments to the course as it proceeded, and plan changes the next time it would be offered.

Even the seating arrangement was designed to increase students' comfort zone. Sometimes, in whole class discussions, we had them sit in a semi-circle. When we asked for formative feedback, one student wrote:

The way we sit in class also has an effect on how we enjoy the class. It may seem like an absurd comment but, when we sit in a semi-circle, there is a feeling of comfort and people may be less nervous to speak.

\section{Assignments: Incremental educational outcomes}

It was essential for us to remember that the level of philosophical literacy aimed at would be achieved incrementally over the two terms. Consequently, the assignments were staged and developmental. The British Department of Education \& Science, The Cox Report (1988b, p. 47) expresses this succinctly, "if proposals for assessment are to have coherence, they must be based on a theory of difficulty." There were, therefore, three types of assignments which are elaborated on below: (a) the personal philosophical journal, (b) a portfolio of structured pieces, and (c) two extended essays.

(a) The personal philosophical journal. The personal journal provided a forum where students could seize the opportunity to use language informally, to write short pieces frequently, to learn to write, to write to learn, and gradually to build up confidence in themselves as writers. More importantly, the journal made it possible for them to use language in different ways and experiment with different rhetorical modes including poetry. In commenting on the value of informal writing, Marwine (1989) points out that, ". . . it should serve as a means for discovering, probing, speculating, questioning, inventing, reacting, connecting, believing and doubting" (p. 65).

Students did begin to think of philosophy as dialogue, and carry on a dialogue with the texts which they were reading. For example, The Trial and Death of Socrates generated short entries on the philosopher's attitude towards death, the after-life and the immortality of the soul. Others dealt with controversial contemporary issues, as one student questioned the moral values of defense lawyers who represented criminals accused 
of heinous crimes, while one Native student expressed outrage at the theories of genetic superiority discussed in her psychology class. These very short pieces were invaluable as they provided an opportunity for students to begin to apply the rhetorical variables as they tried to analyze their purpose for writing the entry and determine the possible audience.

(b) The portfolio of structured pieces. Here, the pieces were more structured and challenging. Students could choose from a range of 17 short assignments which make different cognitive, linguistic and rhetorical demands, and submit six pieces each term. These included:

1. Probing a memorable line from one of the texts being studied, for example, the axiom from The Trial and Death of Socrates, "The unexamined life is not worth living," and connecting it with their own lives;

2. Grasping the main idea of a reading by identifying the topical issue, the author's stance on the issue, support offered for that stance, and the student's response to the piece;

3. Comparing ideas, in an analysis similar to exercise 2 , but involving a comparison of the positions of two authors on a common issue;

4. Analyzing one position from the standpoint of another, which is a variation of exercise 3 ;

5. Defending a proposition in a 4 paragraph format, while also providing a descriptive outline that identifies the proposition defended and summarizes the content of each paragraph and its strategic function in the short paper (Bruffee, 1972);

6. Writing a moral debate, developed by students working in small groups, in a prescribed format, which has both individual and group components.

The following excerpts from item (3) illustrate a student's attempt to compare "Utilitarianism and Vegetarianism" by Roger Crisp with “Animal Liberation" by Peter Singer (1992).

(i) What is the main issue that both authors address?

Singer and Crisp address the issue of how we should regard animals, specifically in relation to their suffering and whether we should use them as a source of food. 
(ii) What is the main claim of each author on this issue?

Singer argues that animals raised for food production are treated in a cruel fashion and endure suffering. He concludes that all suffering is morally wrong and therefore we should not use animals for the purposes of food.

Crisp deduces that we are morally obligated to eat non-intensively reared meat, because so long as animals live pleasant lives, the very reason that we eat meat may be the cause of their existence.

(iii) Summarize the reasoning of each author:

(Following a summary of Singer's reasoning, the student continues):

Whereas Singer's line of reasoning is based on the Bentham theory of equality, Crisp bases his reasoning on the utilitarian principle of what is best overall for the most. Singer brings forward information to determine a rational conclusion, whereas Crisp works backwards from his conclusion to demonstrate his reasoning.

Crisp begins his writing by describing the different utilitarian positions from which he will work. He uses the process of elimination as he works through the arguments against the stance that we ought to eat meat.

Note that under the prescribed format, this student says too much under (ii). Only the underlined portions should have been included, with the remainder relegated to reasoning under (iii).

The following excerpts on Gun Control illustrate our debate format (item 6 above, adapted from Maner, 1977). This text was co-authored by two students. The section, "Objection 1 to Argument 1 for view A" is not entirely logical. However, the excerpt shows students who have made some progress with a new genre.

\section{MORAL ISSUE:}

Should the government pass legislation banning the private ownership of firearms? 


\section{CONTRARY VIEWPOINTS:}

A: Yes, the government should pass legislation banning the private ownership of firearms.

B: No, the government should not pass legislation banning the private ownership of firearms.

\section{ARGUMENT 1 IN SUPPORT OF VIEW A:}

1. If there are less guns, there is less crime., e.g. Japan and England have strict gun control laws and fewer crimes are being committed. (factual premise)

2 . The government should reduce crime in society for the well-being of all citizens. (moral premise)

Therefore, the government should pass legislation banning the private ownership of firearms. (conclusion)

\section{OBJECTION 1 TO ARGUMENT 1 FOR VIEW A:}

- Japan and England, although having fewer crimes, differ in culture, politics and idealism compared to North American society. (factual premise)

- Citizens do not have the same rights and freedoms as there are in Western [sic] society. (factual premise)

Therefore, no one can say if there are less guns crime will be reduced in North American society. Premise 1 of Argument 1 is unfounded.

\section{ARGUMENT 2 IN SUPPORT OF VIEW A:}

1. The chances of accidental firearm fatalities among children increase with the increase in firearms. (factual premise)

2. Government should protect children from unintentional firearm death. (moral premise)

Therefore, the government should pass legislation banning the private ownership of firearms. (conclusion) 


\section{OBJECTION 1 TO ARGUMENT 2 FOR VIEW A:}

- Accidental death among children is not due to handguns but to the irresponsible people who make loaded guns accessible to children. (factual premise)

- Any responsible gun owner who takes the necessary precautions to ensure a safe environment will not have accidents.

Therefore, Premise 1 of Argument 2 is false.

Arguments 1 and 2 above represent the "pro" side of the debate. Additional arguments, with corresponding objections, were presented for the "con" side as well.

The debate format is introduced as a specialized form of dialogue that illustrates features of constructive argumentation, such as validity and relevance, by imposing a logical structure on material selected by the students themselves. Groups of three to five students each select a moral controversy to develop into a debate. First they must sharpen their broad issue into a specific moral question and identify two contrary pro and con positions. They then produce an array of arguments and counterarguments, objections, replies, and counter-replies, to explore various lines of reasoning and critique that might be brought to bear on the question.

(c) Extended essays. The structured assignments described above call for a variety of kinds of writing and analysis of different degrees of complexity and difficulty. However, the most sophisticated assignments we ask our students to perform are the extended essays written towards the end of each term.

In the first term, they write on the quest for the good life. We ask them both to theorize about a philosophy of life to which they might subscribe and to draw on illustrative personal experience. Their reflections should address aspects of personal goals and fulfillment, and of underlying moral principles. They should also try to engage the views of Socrates or others on these matters.

The second essay, on a contentious moral issue, carries the expectation of more attention to argumentation and background research on the issue. The successful completion of this essay embodies the long term attainment target for the course, which should put students in a good position to succeed in other philosophy and humanities courses. By the end of the course, we expected students to have reached a level of philosophical 
literacy through reading, engaging discourse reflectively, and constructing philosophical texts. Then they could produce an acceptable mature philosophical essay on a moral issue involving

a. some research;

b. accurate representation and interpretation of sources;

c. recognition and comparison of similarities and differences of viewpoints;

d. critical analysis, in which the logic and assumptions of moral positions are identified and tested; and

e. drawing and defending conclusions of their own responsive to the views considered.

Throughout the writing assignments, students worked through the range of processes - social, cognitive, linguistic and rhetorical, to which reference has already been made. Initially, they were helped and supported by brainstorming, a number of other invention strategies, small group discussions, as well as an opportunity to clarify their ideas and test out their positions in one-to-one conferences with one of their instructors. Then the peer review process enabled them to distance themselves from their work momentarily. Finally, our detailed response to an original draft gave students enough feedback and encouragement to revise and improve their texts.

We have recounted, at some length, the rationale and design of the curriculum, with examples of students' work in response to two of the shorter assignments. What did we learn about the students? How well did they perform?

\section{Part III - Evaluation}

This section includes a report on student observations solicited part way through the course and at the end, brief evaluative information which arose from the initial attempt to implement the integrated curriculum and an account of a few of the changes which seemed necessary. This then leads to speculation about some of the variables which might have impacted on student performance. The final section places some general questions which arose from the first year of the experiment within a broader context. 


\section{Student evaluations: Formative and summative}

Student evaluations may be differentiated into two distinct, but interrelated types in terms of their timing and sequence. First was the series of monthly formative evaluations, in which we asked them to document the strengths and weaknesses of the course, and, perhaps more importantly, their suggestions for its improvement. Student concerns pertained initially to their confusions about the aims and objectives of the course, the instructors' expectations, the nature of a particular assignment, the allocation of time between philosophy and writing, the demanding nature of the course, and the difficulty of some of the philosophical concepts. These criticisms were very helpful in the ongoing process of curriculum development, and will be discussed further.

In addition to the dialogue generated by the formative evaluation and response over the course of the year, we invited a final assessment at the end, as we sought answers to questions like: How did the students themselves view the experiment overall? What did the integration really mean to them? To what extent were the classes inclusive and representative of a "pedagogy of possibility"? Negative responses included comments like:

I never liked the idea of having two professors. One teacher with both a philosophy and English background would have been better.

Philosophy takes up more than its half, and we are getting short-changed on our half English credit.

I feel serious constraints of time. We do not have enough time for either philosophy or English.

I do not like group work. It is a personal thing caused by fear, which I am perfectly happy to live with.

But responses such as the following encouraged us to think that our effort was worthwhile after all:

The strengths of the course are that we are being taught to write - to communicate. If philosophy is to be a dialogue, then to learn how to communicate in any way would be to continue to learn to write. 
This course is great. It is by far the best class I' $m$ attending this year. This is practically the only class all week I look forward to attending.

This course offers many positive things. One of the factors could be the group work, people helping each other in the class.

This course has a strong point in that group discussions are free-flowing, so new thoughts and ideas are unrestricted. The course material has given me some personal insight and thought-provoking subjects/topics.

I think this English/philosophy class is interesting. I look forward to coming to the classes, and I enjoy the time spent in them. I find this class to be not as "uptight" as the three other courses I am taking, simply because of the groups and general openness of its members.

To begin with, I had hesitations about being in an English course, and to complicate my insecurities, philosophy really scared me, but I took this course because I needed it to graduate. To my elation, I like the course. Why? I feel our ideas are well received and not criticized. Having two instructors is great. It really helps to facilitate an intimate atmosphere. I also feel that we are given plenty of time to work in groups without feeling any pressure to hurry.

In the end, the classroom climate and the type of integration we were attempting, provided quite a favourable experience for some of the students.

\section{Gleaning more evaluative information}

While the formative evaluation of the course provided by students was valuable, our perspective as instructors was also crucial. Consequently, we began to examine the theoretical and pedagogical underpinnings of the curriculum as critically as possible. More importantly, it was necessary to question and challenge our assumptions within the context of the living classroom. Odell (1993) reminds us that "theory and practice are interactive, each capable of informing and remaking the other" (p. 2).

The concept of dialogue which drove the curriculum design, philosophy as dialogue, the teacher-student relationship as dialogue, highlighted the central role of students in the whole educational process, and the assumption that they would be active partners in every phase of the 
learning process. It was essential to try to assess what students brought with them to the course, and the ways in which their skills, understandings and insights would impact on the delivery of the curriculum. But, at another level, it was also critical to discover what uncertainties and frustrations this new, untried, "non-linear" curriculum model was generating in their minds.

We therefore cast ourselves in the role of "teachers as learners," a concept which is by no means new, but which has been dealt with by Freire (1970), Shaughnessy (1977) in her seminal work with "basic" writers, and Peterson (1993) among others. In a sense, a good deal of data was generated as we listened, observed, noted a class which went well, or was mediocre, and tried to intuit what worked and what did not. Shaughnessy (1977), who regards students as important resources for teachers, refers to those processes by which "we open up students' secret files of misinformation, confusion, linguistic insight to an extent not often possible in the traditional setting" (p. 40).

The attempts to gather "data," to conduct a kind of dialogue with our teaching needed to be taken a stage further, through thinking and interpreting the knowledge gained. Schon (1990) uses the term reflection-inaction to describe the grappling with questions, which serve "to shape and reshape what we are doing while we are doing it" (p. 26). In the words of Peterson (1993), "we were able to play with possibilities in ways that generate new questions, uncover previously hidden connections among processes, or suggest alternate models" (p. 22). What modifications were made to the curriculum as a result of these strategies which we employed?

\section{Some curricular changes}

There was an urgent need for the course to be organized in such a way that students had a clearer set of expectations. Because they were confused and uncertain about what needed to be done in preparation for classes, every effort was made to address their concerns either at the beginning of classes or in the time slot at the end of each class. In addition, the weekly schedule was carefully revised so that it became very clear what was the topic, the prescribed reading, the nature of their interaction with text in preparation for class, written assignments, and the class activities scheduled for each Tuesday and Thursday. 
Current literature and research in the teaching of writing strongly emphasize the different ways in which the content of a discipline shapes and reshapes a writer. Because the written work was structured around a theory of difficulty, it was very surprising that some students seemed so uncertain about the simplest assignment: the journal entry. However, some of the more confident students shared their efforts with the class, and gradually all had a sense of what was required. In general, there was need to sensitize students to different genres. (See Walvoord \& McCarthy (1990) for an in-depth discussion of students' responses to written assignments in four disciplines.)

This experience led to a much more studied attempt to anticipate some of the difficulties which students would encounter with the portfolio of structured pieces. Each of these written texts represented a new genre which required a knowledge of specific content as well as "procedural knowledge". A range of pedagogical strategies were used to help students understand how each task should be done. Sometimes, the first step was the clarification of a concept with which students had to work. Before they could be led through the processes and methods required to co-author a moral debate, a short film entitled "The Lifeboat" was used to help students to understand exactly what is meant by a moral dilemma and moral choices.

The two major extended essays represented the greatest level of difficulty because each had multiple interlocking parts. The strategies which we employed were also used by Kauffer and Young (1993) and could be described as dissecting assignments to identify multiple tasks, clarifying areas of difficulty, then setting up "a series of smaller assignments or activities to build experience or understanding progressively" (p. 88). The persistence and thoroughness with which students negotiated these incremental steps were reflected in the quality of their completed assignments.

One of the most crucial findings was that many students were weak in the analytical skills which are so fundamental to philosophy and other disciplines. It seemed imperative that we should do more to foster these skills. A major change in the second year of the course was the use of John Chaffee (1994), Thinking Critically as the text. Through readings on interesting topical issues, creative exercises and a video-taped discussion, Chaffee leads the students through an array of thinking skills related to decision-making and the analysis of controversial issues. We found his approach quite compatible with an attempt to integrate the 
teaching of philosophy and rhetoric and can recommend this text for consideration by others with a similar objective.

\section{Instructors' evaluation of student performance}

The first year of the experiment raised a number of issues, one of which is the gap between equality of opportunity and equality of access. We provided the same educational context for all the students, but a number of variables, known and unknown, made it impossible for all of them to profit equally from the course or even to complete it. For example, 39 names first appeared on the class list, but there were 5 "no shows," thus leaving a total of 34 students. Of these, 8 withdrew from the course overall.

School Leavers Survey (1992b) documents a range of environmental, social, educational, attitudinal, and economic factors which impacted on the lives of students and militated against their completing high school nationally. Perhaps some of these factors were also operating in the lives of the students who first registered. There were also specific circumstances which militated against course completion. For example, one student had her registration cancelled, while another withdrew from the University. Three others who experienced the tension between their course load in the University and the demands of the workplace also withdrew. It is interesting that one of them returned the following year and successfully completed the course.

Three of the remaining 26 students failed because they did not complete all the assignments. One undergraduate handed in only one, while another submitted two. The third was the unusual case of a science student who enjoyed the class atmosphere, participated fully in discussions, but could not overcome a writer's block to produce even the briefest journal entry.

What about the 23 students who successfully completed all aspects of the course? How well did they achieve the course objective? Because we regarded the final assignment, which was the argumentative research paper, as the chief index of philosophical literacy, student performance on this complex assignment seems an appropriate indicator of achievement. Of the 23 students, 3 scored in the A range; 8 in the $\mathrm{B}$ range (four $\mathrm{B}+\mathrm{s}$, four $\mathrm{Bs}$ ); and 12 in the $\mathrm{C}$ range (five $\mathrm{C}+\mathrm{s}$ and seven $\mathrm{Cs}$ ).

Overall, the A and B grades suggest a modest level of attainment of our original philosophical literacy goals. Our expectation is that these students are reasonably well equipped with the writing skills to succeed 
in future arts courses. These results are commendable, especially when we recall that the very best students are exempted from meeting the writing requirement. Those who were performing at the $\mathrm{C}+$ and $\mathrm{C}$ levels will probably continue to experience some difficulties writing essays in senior arts courses. What is hopeful, however, is that they persisted to the end and have developed at least a basic level of analytical, argumentative and rhetorical skills.

\section{Student success: Possible variables?}

There was such divergence among this cohort of students that it is useful to speculate on the variables which might have contributed to student success. Gender, language, age/maturity will be briefly explored. However, the three variables cannot be treated with the same rigour which would apply to an empirical investigation.

An attempt was made to determine whether gender differences affected student performance. Were the female students performing better than males? At first, when the means of the grades for each group was computed, the performance of male students seemed to be marginally higher:

$\begin{array}{ll}\text { Male } & \text { Female } \\ \mathrm{n}_{1}=10 & \mathrm{n}_{2}=13 \\ \mathrm{x}_{1}=71.0 & \mathrm{x}_{2}=68.07692 \\ \mathrm{~s}_{1}=8.43274 & \mathrm{~s}_{2}=11.28023\end{array}$

When the t-test was applied, however, there does not seem to be any statistical evidence to conclude that female students do better than the male students.

The next question centres on language. Were students for whom English was a second language (ESL) more or less successful than native English speakers? There were 4 of the former and 19 of the latter. The general answer to this question, which has already been discussed, is that the most crucial factor for all students, irrespective of their linguistic and cultural background, is their level of language acquisition. If students have acquired the phonology, an adequate vocabulary, the syntax and morphology, and the semantics or meaning component of English, then they will successfully meet the demands of the course. The converse is equally true. The two ends of the attainment spectrum will be used to illustrate this principle more specifically. 
The three highest grades were earned by students who wrote quite sophisticated papers which integrated the multiple demands of composition, research, logical thinking, argument critique and controversy analysis. Their chosen topics included the life and death issues of capital punishment, euthanasia and the ethics of controlling performance-enhancing and recreational drug use. All three drew from an extended bibliography and wove analyses of factual materials and ethical assumptions into a systematic treatment of the pros and cons of their issue. Their essays engaged the readers' interest and led to an informed and reasoned conclusion after an examination of alternative viewpoints and arguments. The native languages of these three undergraduates were (a) English, (b) Ojibway, and (c) Hindi respectively.

At the lowest end of the spectrum were the seven students who earned $\mathrm{C}$ grades. Two of these were ESL. Reference has already been made to these two students whose native languages were French and Spanish respectively. Their observations about their level of language acquisition have already been cited. These included thinking in French and translating into English, an inadequate grasp of vocabulary, uncertainty about syntax and morphology, and a lack of confidence.

These students who accurately diagnosed their linguistic and writing abilities had the option of obtaining extra help from their instructors as well as peer tutoring from the Computer Writing Laboratory or the Writing Centre. It is not known what factors prevented them from seeking these opportunities to develop their linguistic and writing abilities. LePage and Tabouret-Keller (1985) present more than a decade of research in language acquisition, which was conducted in the Caribbean and London. These linguists regard language acquisition as 'acts of identity' and explain why some students are much more successful than others in acquiring other languages.

The other five students who earned Cs were native speakers of English. Although admission standards might be a contributory factor here, it is still puzzling why native speakers who have been exposed to a language all their lives should still experience linguistic and writing problems. However, this question is discussed in depth in the final section.

Age/maturity seemed a major determinant of success. Here, the term is being very cautiously used because we did not ascertain the exact age of each student. However, Moss and Walters (1993) observe that more mature students "bring life and work experiences into our classes that affect the way they value school and many of its practices... These students have 
different kinds of goals and different strategies for reaching them" (p. 164). The mature students in the course were highly motivated and had a strong sense of purpose. These factors, along with their persistence, were major correlates of their success. Much more needs to be known about the range of factors which might have a negative impact on the work of some of the younger students, in particular, those who are making a transition from high school to university.

\section{Part IV - Problems and Issues}

$P D$ : The experiment raised a number of questions and concerns which, I think, we ought to address, however, tentatively. The first is the struggle which writing represents for some students. After all, English is required in all sectors of the educational system. Are the difficulties which some of our high school graduates experience unique to this university or the province of Manitoba?

WP: Whether or not it is valid, there is nothing new in the criticism that the linguistic and writing skills of some high school graduates have not fully prepared them for universities. For example, Besner, Huff and McIntyre (1988) comment on the $40 \%$ increase in the enrolment of the University of Winnipeg between 1982 and 1985, the changing demography of the incoming students and "groups who were poorly prepared (or indeed completely unprepared) for the language demands which would be made of them" (p. 8).

However, there are two important caveats to be borne in mind. First, there is no national examination which is a terminal point for all Canadian high school students. Consequently, there is no body of written texts from which meaningful comparisons about student performance in English could be made across all the provinces at this point. Literacy Skills of Canadian Youth (1997) does provide a comparison of literacy levels among the 16-25 age group for Manitoba, Saskatchewan, Ontario, New Brunswick, Newfoundland and Prince Edward Island. However, this is described as knowledge and skills about "prose literacy," "document literacy" and "quantitative literacy."

Secondly, the University of Winnipeg does attract a large cohort of high calibre students to whom further reference will be made. These undergraduates fully justify the University's commitment to the twin goals of access and excellence. 
But, it must also be noted that dissatisfaction with the writing abilities of undergraduates has been a recurrent theme in the literature past and present. Broadus (1927) criticized poor student writing at the University of Alberta, and made suggestions to address the problem. The Association of Canadian University Teachers of English 1976, Acute 6 (as cited in Schryer \& Steven, 1994) advocated the need for remedial courses to help students acquire the "level of competence they should have achieved prior to entering the University." Graves (1994) indicates that "for a time in the mid-1970s and into the 1980s, universities and high schools argued over the causes of the poor writing skills of their students" (p. 8). McManus (1991) after a survey of writing programs in Canadian universities suggests that "the common factor for all programmes is perhaps the sense of urgency each has to find solutions to the many problems students have thinking critically and writing" (p. 11), (see also Dowler, 1994; Procter, 1994; and Schryer \& Steven, 1994)

$P D$ : Well, another related question concerns students' abilities to grasp and expound arguments. Should these skills not have been learned before they arrive at university?

WP: Like my colleagues in the Writing Program, I do not find that, at the introductory level, all undergraduates begin a course with a strong sense of genre, nor the skills of critical thinking which contribute to their ability to grasp and expound arguments. In an attempt to provide an explanation, however tentative, I perused Manitoba High School English curricula which were relevant to the students under discussion. For example, Curriculum Support Series (1991, p. 126) outlines the following range of written formats expected of students from Grades 9-12: Personal Writing, Writing for Oral Presentation, Imaginative Writing, Short Precise Writing, Legal Writing, Longer Transactional and Journalistic Writing. There were large numbers of written exercises suggested for these seven categories, and argument was mentioned once.

I also had informal talks with some English teachers and a Curriculum Consultant of the Ministry of Education and Training in the province. However, it is hazardous to make any generalizations on such slight evidence. I strongly posit the view that only systematic, longitudinal, empirical investigation could provide any meaningful answers to the complex question of language learning and teaching, critical thinking, and the development of students' abilities to grasp and expound arguments. Perhaps, it is also worth noting that a good deal of curriculum 
restructuring is currently taking place. There is now a provincial English examination. What is interesting also is that Alberta, British Columbia, Manitoba, Saskatchewan as well as Yukon and the Northwest Territories are currently engaged in the development of a Common English Curriculum (see The Common Curriculum Framework, 1996).

But concern about the skills of argumentation comes from another geo-political area. Bizzel (1982) expresses the view that more and more students have come to college who cannot sustain an argument in an essay. Kantz (1990) observes that "the task of writing research papers that express original arguments presents many difficulties to students" (p. 74), a view shared by Bazerman (1995). In addition, Procter (1994), in her survey of 400 students' attitude to writing, found that 135 criticized their own weakness in the organization of their arguments.

Kantz (1990) goes further and argues that "we need a theory-based explanation, one grounded in the findings of published research on the nature and reasons for our students' problems with writing persuasive research papers" (p. 74). But in the final analysis, we can only "start where students stand," and try to move them along a continuum of insight. That is why there is such a fully articulated Writing Program (now renamed the Centre for Academic Writing) with such strong institutional support. However, we need to widen our discussion to include another cohort of students.

$P D$ : Yes, the institution continues to attract many students of high calibre. Because the focus of the institution is on undergraduates, many have the opportunity to participate in research either on their own or in collaboration with members of faculty. For example, in a survey of undergraduate student involvement in formally presented and/or published research between 1988 and 1995, Rannie (1996) notes "293 papers that involved 206 different students and 60 faculty members" (p. 3). In addition, there are a number of other honours and awards which accrue to students. The University of Winnipeg President's Report to the Community, 1995-96: Demonstrating Excellence (1996) lists numerous such awards, including, for example, two Rhodes Scholarships in the last three years and 13 Undergraduate Student Research Awards from NSERC in 1996; the highest number allotted to any university in Canada.

WP: Despite the difficulties which we have raised, you, a busy chairperson of a department, agreed to repeat the experiment in the following year. Why? 
$P D$ : I wholly endorse the University of Winnipeg's commitment to making a rigorous program of higher education accessible to a broad spectrum of students of varying backgrounds and life circumstances. We cannot forget that $100 \%$ of the 23 students who completed their assignments demonstrated that they had developed varying degrees of proficiency in philosophical literacy, which, on the evidence of their struggles and earlier work, they lacked at the outset of the course. That was worthwhile, whatever the cost.

I suppose there is an alternative, namely a more elitist system, which would simply disqualify certain students from obtaining a university education. But we, as a society and as an institution, have made a choice against such a highly stratified system in the interests of promoting social mobility, educational equity, an informed and critical democracy, and the labour force needed for an increasingly knowledge-based economy. One crucial question which still needs to be asked, though, is whether this experiment is a direction which we can expect other universities to pursue with their ever-shrinking resources, increasing class sizes and greater demands on a professor's time?

WP: Many institutions of higher education currently face a serious dilemma: a kind of educational paradox. Graves (1994, p. 71) comments on the increase of writing programs in Canadian universities within the last two decades, and indicates that "administrators are increasingly accepting the argument that universities need to provide writing instruction." However, these institutions of higher learning are engaged in the challenging task of balancing the tension between the need to continue to develop students' writing abilities and sharp fiscal restraints.

The question posed earlier is a difficult one to answer because as co-authors, we do not have access to information which would enable us to make an informed judgement about all Canadian universities. Indeed, McManus (1991), who draws on her survey of writing programs, reminds us "that the mix of standards, students and budgets is unique for each campus; the program each campus develops should reflect its own needs and fiscal reality" (p. 11). Despite this caveat, I will venture to express an opinion.

Money is not the only factor to be considered. When there is sufficient interest and motivation to try new disciplinary initiatives, then a way will be found. Indeed, current literature and research in the field represent a kind of invitation to faculty to cross "disciplinary barriers." 
Russell (1991), among others, reminds us that "writing [is] no longer a single, generalizable skill learned once and for all at an early age; rather [it] is a complex and continuously developing response to specialized text-based discourse communities" (p. 5).

What was the actual cost of our experiment? In the first year, no expense was incurred. We taught the equivalent of a half course over our normal load, but the time was donated. At the end of the second year, I was offered a half-course release. So the total cost of the two-year experiment was a little less than three thousand dollars, the price paid to staff the half-course. But, it is essential to balance the expenditure of time and money against the long-term gains of a composition teacher and content expert. Kauffer and Young (1993) provide strong support for this statement as they balance the tension between financial costs and those educational gains which cannot be easily quantified in dollars and cents.

In assessing their intensive Biology and Rhetoric course, they admit that constraints of time and money could militate against its large-scale implementation in Carnegie Mellon University. Then they document the following pedagogical, theoretical and epistemological gains:

If we judge by its educational outcomes, it has been very successful ... The amount and diversity of writing in the biology courses has increase substantially... As an exercise in exploratory research it has been invaluable. We have learned much about language practices in another disciplinary community ... and about disciplinary interaction across disciplinary communities (pp. 88-89).

So what are the long-term benefits for us and the institution? What have we learned from the experience?

$P D$ : I dare say we both appreciate more fully the intermeshing of philosophical reflection and rhetorical skills. I, for example, have gained a new appreciation of how the rhetorical variables function to define a range of communicative styles. I have also learned additional techniques for invention, peer editing, and other processes of writing. There are many other lessons that are harder for me to articulate, learned from your raising different questions than I might raise and modelling a different classroom style, a mixture of sternness, humour and invitation as you struggle with your students' writing difficulties and draw them into a collegial sharing of their creations with one another. 
We now have a better grasp of the possibilities and limits of developmental education for some first year undergraduates in our institution. But there are still a number of unknown variables which impacted on some of those students who did not complete the course. This will be the focus of research which I hope to pursue this year. However, the most enduring benefit of the course for me has been that I now know how to devise a course in philosophical literacy, but more importantly to implement it completely on my own.

The experimental course might be described as a small project. What is highly significant, however, is that I now apply what I have learned to a much larger number of students. With the help of a teaching assistant, I now teach a modified version of the original course to 65 students in my introductory philosophy class.

$W P$ : This has been a learning experience for me with long-term benefits, the first of which is institutional. As a teacher of composition, I need to respond positively to the new pedagogical mandate which arose out of the Writing Program Reviews in 1993: to make a transition from cognitive to social epistemic rhetoric and to make a greater connection between the writing requirement and the needs of different disciplines. Such a goal is in keeping with major trends in composition theory and research, and with Writing in the Disciplines in higher education. But this objective represents an epistemological leap and a major challenge to the teacher of composition, who, like myself, is an "outsider" to the social sciences, the natural sciences and, partially so, to the humanities.

I must concede that many scholars including Bazerman (1991, 1988), Simons (1989), and McCloskey (1983) have provided invaluable insights into the dynamics, the social contexts, the assumptions and the rhetorical conditions which shape writing in different fields. In addition, Jolliffe (1988) and Walvoord and McCarthy (1990) have further enriched our understanding of writing in the disciplines through longitudinal, empirical research. But I needed to supplement the insights gained from scholarly research by listening to the authentic voices of professors in different fields in the University of Winnipeg.

So, throughout the integrated course, you made explicit to me, an "outsider," what in your view is the culture, the practices normative to your discipline, and the written conventions in your field. You achieved this, as you alternated the rules of expert in the social construction of philosophical knowledge, co-presenter, resource person, member of the 
whole class, and a participant in small group writing activities. Although this might seem like a small step towards the institutional goal already described, in a real sense, I feel that I have not only begun to bridge the epistemological gap between cognitive and social epistemic rhetoric, but also connect the writing requirement to the needs of disciplines.

Another developmental gain for me has been pedagogical. The needs and abilities of student writers, and the ways in which they negotiate courses in different disciplines in the university have been a concern of a number of composition theorists and researchers. For example, Shaughnessy (1977) and Zamel (1995) conceptualize some students as strangers in the university who experience difficulties with their writing because they are unaccustomed to the conventions of academic discourse. Bartholomae(1985) articulates the tension between students needing to "reinvent" the university as they write for different courses and appropriating a language that has already been invented. Harris (1989), on the other hand, argues that "student discourses are already partly academic; what is needed is complicating their uses of language" (p. 17).

Again, theory needs to be supplemented with practice, and the classroom context provided an opportunity for us to gain new insights into writing and its pedagogy. Russell (1991) advises us that we not only need to "understand how a discipline constitutes its discourse, but how writing plays a role at various stages of their initiation into that community" (p. 301). These learning experiences took place for us as we worked through the various recursive processes of writing with the students, held one-to-one conferences with some, and engaged in informed discussions of the rhetorical and linguistic aspects of their assignments.

This dialogic approach to writing which privileges both the expert in the discipline and the composition teacher is strongly supported in the literature (see Blair, 1983; Fulwiler, 1989; and Knoblauch \& Brannon, 1983). But, it is Kauffer and Young (1993) who neatly encapsulate this approach as they urge the need for "cross cultural communication and collaboration" (p. 102) in any attempt to develop writing programs in the content areas, and observe that "neither the writing teacher nor the content teacher can select the role of anthropologist or native. Both must play both roles. Both must be willing to travel."

WP and PD: Our course had its problems, but enough found it worthwhile to make it gratifying to us. How could we not carry on, with a tribute like this from one of our students: 
I not only enjoy this course, but find it as an enlightenment. It is not monotonous nor useless. It has given me insight on how to read, interpret/understand a piece of literature or article and appreciate or debate the writer's views. This also helps me understand styles of writing. I have never actually encountered such an interesting class in university where my mind can run free with thoughts and ideas, as well as get my doubts answered. I can actually express myself and not be afraid to speak or converse with strangers or be ashamed of letting someone read my writings. I appreciate the unity of this class in helping each other learn and/or better our skills.

The philosophy I have learned before is not going to only remain in my mind but be applied to my journals as well as style. The thought of having two professors teaching us is something I've always dreamed of in a class. It is full of life and enthusiasm and it makes me want to show up and prove myself. It is exercising my brain as well as relaxing and relieving my mind of stress. I am eager to learn and acquire more. As for improvement, there is no better way than what has already been done - a class working in groups, you hearing all of our opinions, giving us chances to do so by asking and then giving yours or correcting us and helping us to reason as well as improve our styles. I couldn't ask for more not at this point.

\section{References}

ACUTE (1994). The need for remedial English in universities: A statement by the association of Canadian university teachers of English. In C. Schryer, \& L.Steven (Eds.), Contextual literacy. Writing across the curriculum. Winnipeg, MB: Inkshed Publications.

Bartholomae, D. (1985). Inventing the university. In M. Rose (Ed.), When a writer can't write: Studies in writers' block and other composing problems (pp. 134-165). New York: Guilford.

Baktin, M. (Ed.). (1981). The dialogic imagination. Austin, TX: University of Texas Press.

Bazerman, C., \& Paradis, J. (Eds.). (1991). Textual dynamics of the professions. Madison, WI: University of Wisconsin Press. 
Bazerman, C., \& Paradis, J. (Eds.). (1988). Shaping written knowledge. The genre and activity of the experimental article in science. Madison, WI: University of Wisconsin Press.

Berlin, J. (1987). Rhetoric and reality: Writing instruction in American colleges, 1990-1985. Carbondale, IL: Southern Illinois University Press.

Besner, N., Huff, R., \& McIntyre, M. (1988). Writing program, University of Winnipeg. Inkshed, 7(2), 6-10.

Bizzell, P. (1982). Cognition, convention, and certainty: What we need to know about writing. Pre-Text: A Journal of Rhetorical Theory, 3(3), 213-243.

Blair, C. (1988). Opinion: Only one of the voices: Dialogic writing across the curriculum. College English, 50(4), 383-389.

Britton, J., Burgess, T., Martin, N., McLeod, A., \& Rosen, H. (1975). The development of writing abilities $(1 /-18)$. London: Macmillan Education. School Council Research Studies.

Broadus, E. (1994). The weakness in English of large numbers of graduates and undergraduates. In R. Graves (Ed.), Writing instruction in Canadian universities. Winnipeg, MB: Inkshed Publications.

Bruffee, K. (1972). A short course in writing. Cambridge: Winthrop Publishers.

Canada Year Book. (1992). Ottawa, ON: Statistics Canada.

Chaffee, J. (1994). Thinking critically. Toronto, ON: Houghton Mifflin.

College Composition and Communication. (May 1985). xxxvi. Urbana, IL: National Council of Teachers of English.

Corder, S. (1981). Error analysis and interlanguage. Oxford: Oxford University Press.

Crawford, H., \& Smouth, K. (1995). An interview with Charles Bazerman. Composition Studies, 23(1), 21-36.

Crisp, R. (1992). Utilitarianism and vegetarianism. In E. Soifer (Ed.), Ethical issues: Perspectives for Canadians, (pp. 190-200). Peterborough, ON: Broadview Press.

Curriculum Support Series. (1991). Winnipeg, MB: Ministry of Education and Training.

Department of Education and Science (1988b). The Cox report: National curriculum: English for ages 5 to 11. London: HMSO.

Dowler, M. (1994). Determining writing standards for civil engineering students: Implications for writing across the curriculum. In C. Schryer, \& L. Steven (Eds.), Contextual literacy writing across the curriculum, (pp. 21-28). Winnipeg, MB: Inkshed Publications.

Elbow, P. (1991). Reflections on academic discourse: How it relates to freshmen and colleagues. College English, 53(2), 135-155.

Farr, M., \& Daniels, H. (1986). Language diversity and writing instruction. Urbana, IL: National Council of Teachers of English.

Forbes, J. (1993). The inclusive university. Part I: Educational equity. Status of women supplement. CAUT Bulletin, 1, 3, 8.

Freire, P. (1970). Pedagogy of the oppressed. New York: Penguin. 
Fulwiler, T. (1984). How well does writing across the curriculum work? College English, 46(2), 113-125.

Gleason, H. (1961). An introduction to descriptive linguistics. New York: Holt, Rinehart and Winston.

Graves, R. (1994). Writing instruction in Canadian universities. Winnipeg, MB: Inkshed Publications.

Gross, P., \& Levitt, N. (1994). Higher superstition: The academic left and its quarrels with science. Baltimore, MD: Johns Hopkins Press.

Harris, J. (1989). The idea of community in the study of writing. College Composition and Communication, 40(1), 11-22.

Heffernan, J., \& Lincoln, J. (1994). Writing: A college handbook (4th ed.). New York: W.W. Norton and Company Ltd.

Jolliffe, D. (Ed.). (1989). Advances in writing research. (Vol. 11), Writing in academic disciplines. New Jersey, NJ: Ablex Publishing Corporation.

Kantz, M. (1990). Helping students use textual sources persuasively. College English, 52(1), 74-91.

Kauffer, D., \& Young, R. (1993). Writing in the content areas: Some theoretical complexities. In L. Odell (Ed.), Theory and practice in the teaching of writing: Rethinking the disciplines (pp. 71-104). Carbondale, IL: Southern Illinois Press.

Knoblauch, C., \& Brannon, L. (1983). Writing as learning through the curriculum. College English, 45(5), 463-474.

Kroll, B. (Ed.). (1990). Second language writing. Cambridge: Cambridge University Press.

LePage, R., \& Tabouret-Keller. (1985). Acts of identity. Cambridge: Cambridge University Press.

Lindemann, E. (1987). A rhetoric for writing teachers (2nd. ed.). Oxford: Oxford University Press.

Lumpp, A. (1994). Language and power. An unpublished term paper. The University of Winnipeg.

Maner, W. (1977). Practicum handbook for philosophy. Norfolk, VA: Old Dominion University Research Foundation.

Marwine, A. (1989). Reflections on the uses of informal writing. In P. Connelly \& T. Vitardi (Eds.), Writing to learn mathematics and science (p. 65). New York: Teachers College Press.

McCloskey, D. (1983). The rhetoric of economics. The Journal of Economics Literature, 21, 418-517.

McKay, S. (Ed.). (1984). Composing in a second language. Cambridge: Newbury House Publishers.

McManus, K. (1991). Writing programmes and Canadian universities. Newsletter of the Canadian Association for the Study of Writing and Reading, 9(3), 10-12. 
Miller, P. (1993). Philosophical literacy. Winnipeg, MB: The University of Winnipeg.

Moser, J., \& Raphan, D. (1993). Russian students' writing: An adaptation of skills. College ESL, 3(1), 43-55.

Moss, B. \& Walters, K. (1993). Rethinking diversity: Axes of difference in the writing classroom. In L. Odell (Ed.), Theory and practice in the teaching of writing: Rethinking the disciplines (pp. 132-185). Carbondale, IL: Southern Illinois Press.

Odell, L. (1993). Writing assessment and learning to write: A classroom perspective. In L. Odell (Ed.), Theory and practice in the teaching of writing: Rethinking the disciplines (pp. 289-313). Carbondale, IL: Southern Illinois Press.

Odell, L. (1993). Introduction: Theory and practice. In L. Odell (Ed.), Theory and practice in the teaching of writing: Rethinking the disciplines (pp. 1-8). Carbondale, IL: Southern Illinois University Press.

Paré, A., \& Segal, J. (1993). Writing program external review report. Winnipeg, MB: The University of Winnipeg.

Peterson, L. (1993). Learning through teaching. In L. Odell (Ed.), Theory and practice in the teaching of writing: Rethinking the disciplines (pp. 9-39). Carbondale, IL: Southern Illinois University Press.

Plato. (1961a). Phaedrus. In E. Hamilton \& H. Cairns (Eds.), The collected dialogues of Plato. New York: Pantheon Books.

Plato. (1961b). Sophist. In E. Hamilton \& H. Cairns (Eds.), The collected dialogues of Plato. New York: Pantheon Books.

Plato. (1961c). Theaetetus. In E. Hamilton \& H. Cairns (Eds.), The collected dialogues of Plato. New York: Pantheon Books.

Plato. (1977). The trial and death of Socrates. Indianapolis: Hackett Publishing Company.

Popper, K. (1959). The logic of scientific discovery. London: Hutchinson.

Procter, M. (1994). In the box: Students' attitudes to academic writing. In C. Schryer \& L. Steven (Eds.), Contextual literacy writing across the curriculum (pp. 53-63). Winnipeg, MB: Inkshed Publications.

Procter, M. (1995). Post-admission assessment of writing at Ontario Universities: Issues and information. Newsletter of the Canadian Association for the Study of Language and Learning, 13(4), 4-22.

Rannie, W. (1996). Undergraduate edge. Winnipeg, MB: The University of Winnipeg.

Russell, D. (1991). Writing in the academic disciplines, 1870-1990. Carbondale, IL: Southern Illinois University Press.

Schmidt, G., \& Vande Kopple, W. (Eds.). (1993). Communities of discourse: The rhetoric of disciplines. Englewood Cliffs, NJ: Prentice Hall. 
Schon, D. (1990). Educating the reflective practitioner. San Francisco, CA: Jossey-Bass.

School Leavers Survey. (1992b). Ottawa, ON: Statistics Canada Educational, Cultural and Tourist Division.

Schryer, C., \& Steven, L. (Eds.). (1994). Contextual literacy: Writing across the curriculum. Winnipeg, MB: Inkshed Publications.

Shaughnessy, M. (1977). Errors and expectations. New York: Oxford University Press.

Simons, H. (Ed.). (1989). Rhetoric in the human sciences. London: Sage.

Singer, P. (1992). Animal liberation. In E. Soifer (Ed.), Ethical issues: Perspectives for Canadians (pp. 179-190). Peterborough, ON: Broadview Press.

Smith, S. (1991). Report on the commission of inquiry on Canadian university education. Ottawa, ON: Association of Universities and Colleges of Canada.

Soifer, E. (Ed.). (1992). Ethical issues: Perspectives for Canadians. Peterborough, ON: Broadview Press.

Statistics Canada. (1997). Literacy Skills of Canadian Youth. (September). Ottawa, ON: Statistics Canada.

The common curriculum framework for English language arts: Kindergarte to Grade 12 (Grades 10-12 Draft). (1996). Winnipeg, MB: Western Canada Protocol for Collaboration in Basic Education.

The University of Winnipeg. (1986). Senate Founding Document. Winnipeg, MB: The University of Winnipeg.

The University of Winnipeg. (1990). Diversity and excellence in education: An integrated approacb to improving accessibility at the University of Winnipeg. Winnipeg, MB: The University of Winnipeg.

The University of Winnipeg. (1990). Program Review Document: The relation of our past to our present and future. Winnipeg, MB: The University of Winnipeg.

The University of Winnipeg. (1993).The Report of the Internal Committee to Review the Writing Program. Winnipeg, MB: The University of Winnipeg.

The University of Winnipeg. (1993). Report of the Writing in the Disciplines Sub-Committee. Winnipeg, MB: The University of Winnipeg.

The University of Winnipeg. (1993). The University of Winnipeg General Calendar (1993-1994). Winnipeg, MB: The University of Winnipeg, A2-3.

The University of Winnipeg. (1996). The University of Winnipeg Presidents' Report to the Community, 1995-1996. Demonstrating Excellence. Winnipeg, MB: The University of Winnipeg.

Vygotsky, L. (1986). Thought and language. Cambridge, MA: The MIT Press.

Walvoord, B., \& McCarthy, L. (1990). Thinking and writing in college. Urbana, IL: National Council of Teachers of English.

Zamel, V. (1995). Strangers in academia: The experience of faculty and ESL students across the curriculum. College Composition and Communication, $48(2), 506-521$. 